\title{
The Application of Group Work in the Values Education among Vocational College Students
}

\author{
Yuchen LIN \\ Department of Basic Courses of Beijing Information Technology College 100070 \\ No. 90, Xinzhuang, Huaxiang, Fengtai District, Beijing
}

\begin{abstract}
Group work is an effective practice and way to help vocational college students to study and establish the viewpoints of value that combine the group work and students' moral education, and it can be effective to improve the risks of vocational college students' political education to realize the effectiveness of moral education. Through the practice of group work on values education, the result indicated that group work improved students' learning interest on the basis of supplementing and perfecting the teaching methods of moral education. It could guide students to think actively, and help students to make clear and set their values. KEYWORD: group work; values; vocational college students
\end{abstract}

Values are extremely important content in the moral education, and they have essential guiding significance in the realization of life meaning and development of the youth. "Values are the evaluation and cognition of people about the usefulness of all kinds of objects in satisfying the needs of the subjects, and are the combination of the ideologies of basic value that people form in life such as faith, belief, and ideal." Values are the fundamental viewpoint such as, how people understand the value, how to assess the value, and how to realize the value and other issues. While the university period is acritical period for the youth to clear values and establish values. How to help students to construct and gain a clear idea of correct values have become the key points and difficult points for ideological and political education during the effective period of forming correct values. Above all, although vocational college students receive college education, they have their own development characteristics in ideological quality and theoretical acceptance and comprehension, so how to lead and integrate vocational college students to clearly define their life values and social values seems to be very important for their future work and life and the improvements of the development of social grassroots. Group work, which is different from the past theoretical analysis and traditional educational methods of lecture, is a new attempt of building up warm environment, leading students to the new moral education with the goal of leading students' self-exploration. Its functions have been recognized in the field of psychology, and have a significant impact on students' development in physical and mental health. Practice and research have indicated that group work can apply to classes of moral education, and can become a new method and a new way of improving class efficiency[1].

\section{OBJECT AND METHODOLOGY}

\subsection{Research object}

The objects were the vocational college students in the first year of Beijing Information Technology College. They were grouped according to their natural classes and were randomly sampled. One experiment class, in which there were 36 students, with 3 female students and 33 male students, was sampled, and their average age was $18 \pm 1$ years old; the contrast class had39 students, including 4 girls and 35 boys, with their average age of $18 \pm 1$ years old.

\subsection{Assessment tools}

Use the self-compiled "questionnaire of basic knowledge on values" to perform a survey on two classes of students before and after group work to understand the students' knowledge and evaluation of learning effect on the basic knowledge content of value. The scale is around the content of six aspects which are value concept, connotation, life value, social value, value evaluation and value realization, and has six questions and four points of scale scoring. Every project has respectively answered the degrees of understanding on relevant content of 
values. 1 point means knowing nothing, 2 points means knowing a little, 3 points means knowing much, and 4 points means knowing very much. The total score is 24 points and a higher score means more understanding of theoretical knowledge of values. In addition, the "learning effect investigation questionnaire" of self-organization of work has also been made to the experiment class to understand whether the students accept the teaching form of group work and whether the group work is helpful for the students' learning and so on.

\subsection{The scheme and implementation}

The theory of group work program of values includes the related theory of Marxist value, projection and other psychoanalysis theories. According to the specific teaching content of values, the group work sets 3 activity themes, which are "Auction of Values", "The World is Beautiful Because of Me" and "My Book of Life" successively. Each subject has its own target activities and contents, and the three complements each other and builds the theoretical system of values completely. In the process of implementing, conduct researches every week in accordance with the class hour of the syllabus, and conduct the education of values to the contrast class and the experiment class respectively in the form of traditional theory teaching and of group work, and the total class hour is 6 hours. Furthermore, conduct the survey and summarize the total investigation result immediately.

Table 1 Group work scheme

\begin{tabular}{|l|l|l|}
\hline \multicolumn{1}{|c|}{ Theme } & \multicolumn{1}{|c|}{ Target } & \multicolumn{1}{c|}{ Content } \\
\hline Auction of values & $\begin{array}{l}\text { 1. Understand the conception of values } \\
\text { 2. Clear the value of life }\end{array}$ & $\begin{array}{l}\text { 1. Choose a meaningful life through activities } \\
\text { 2. To help students clear their values }\end{array}$ \\
\hline $\begin{array}{l}\text { The world is beautiful } \\
\text { because of me }\end{array}$ & $\begin{array}{l}\text { 1. Understand the social value } \\
\text { 2. Learn the evaluation criteria of value }\end{array}$ & $\begin{array}{l}\text { 1. Draw three pictures of what you do for others or the society } \\
\text { 2. Experience the criteria of social value and value evaluation }\end{array}$ \\
\hline My book of life & 1. Learn how to realize the value & $\begin{array}{l}\text { 1. Draw my own state of the past, the present and the future. } \\
\text { 2. Experience how to work hard to achieve their own value } \\
\text { through painting }\end{array}$ \\
\hline
\end{tabular}

Table 2 The data investigation of the questionnaires on the basic knowledge of values

\begin{tabular}{|c|c|c|c|c|}
\hline Object & Front-test & After-test & T value & P value \\
\hline Experiment class & 12.7 & 19.2 & 10.72 & .000 \\
\hline Contrast class & 12.8 & 13.6 & 1.45 & .146 \\
\hline
\end{tabular}

Table3 The questionnaire statistics of the experiment class's learning effect investigation

\begin{tabular}{|c|c|c|c|}
\hline Research content & Options & Experiment class $\%$ & Contrast class $\%$ \\
\hline \multirow{3}{*}{ whether like the current teaching form or not } & like & $86 \%$ & $53 \%$ \\
\hline & Dislike & 0 & $20 \%$ \\
\hline & Doesn't Matter & $14 \%$ & $27 \%$ \\
\hline Is the current teaching form helpful for learning & Helpful & $88 \%$ & $39 \%$ \\
\hline \multirow{2}{*}{ Contents of this unit are useful } & useless & $2 \%$ & $18 \%$ \\
\hline & It doesn't matter & $10 \%$ & $43 \%$ \\
\hline
\end{tabular}

\section{RESULTS AND EVALUATION}

\subsection{The investigation difference before and after the experiment class and the contrast class carry out the group work (see Table2):}

Through the self-compiled "questionnaire of basic knowledge on values" before and after the guidance on the experiment class, it is found that the average score of students on knowing and mastering the value theoretical knowledge has been increased significantly $(\mathrm{P}<0.005)$.

\subsection{The questionnaire statistics of the experiment class's learning effect investigation:}

Through the implementation of learning effect investigation on students of the experiment class and the contrast class, understand whether students are satisfied with the group work that is applied to Values Education, which serves as one of the indicators when the teaching effect is examined. (See Table 3) 


\subsection{Student works and inspiration}

\subsubsection{Student works}

In the activity, students can explore, comprehend and express their values by means of painting projection. Painting projection technology has been widely used in psychological measurement, consultation and therapeutic process. And the application of painting projection technology in values education and teaching is also a bold attempt. Its basic theory is the spirit analysis technology of Freud. Through the form of painting, it helps students to understand and show their inner established values that are undefined, unspecific and unsystematic. And it externalizes the values in shape, making students feel the strength of their own; Besides, the active imagination technique by Jung Carl Gustav is also applied, for example, in the activity of "My Book of Life", students need to draw their own future life to help themselves actively search for their own value, striving for direction and the ways to realize the value and find their own futures, making their own futures not confusing and clear on the papers.

During the activity, the students made an effort to create. Although they didn't have exquisite drawing technique, they were real and moving. For example, in the unit "the world is beautiful because of me", some students drew family portraits, feeling that the family was full of joy and hope because of themselves; some students drew their own friends, saying that doing something for friends was a kind of happiness and satisfaction; some students drew the pictures of feeding the stray cat themselves, giving the seat to people in need on the bus or protecting the environmental health (see Figure 1), and they said they never knew that they had already done so much for this society, and it turned out that they had been making efforts to do things for others, for many people and for the society in obscurity. And by this activity, the students clearly understand that the life value and social value never contradict and also get knowledge of the evaluation criteria of values. In the activity "My Book of Life", students reflected on their lives and drew up their "yesterday, today and tomorrow", and many students felt the power of the future but also saw that their present situations lacked motivations. For example, as showed in Figure2, a student understood deeply that now he has spent too much time and energies on games but his trouble still lies in no target and motivation; while for the future, the student does have ideals and goals. This activity makes the students see their future and tell themselves the method to realize their value.

Figure1-2 student works

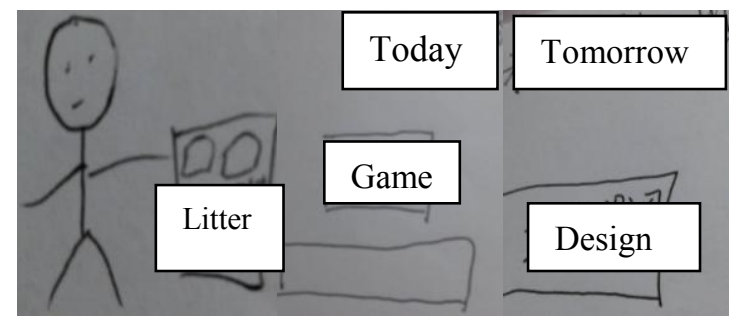

\subsubsection{Students' insights}

Group work not only helps students understand, but also gives teachers an opportunity to know students and feel the lives. Students express themselves truly in activities, and all of their words deserve our deep thinking pondering. "The day after tomorrow is still tomorrow, so live in the present and everyone has his own ambition", "Wish you could pursue success, and always be happy. Dad and mom are very healthy. Also wish myself to see my idol", "From now on, I will play games less, study the computer more, make use of my spare time to look up information, and strive to be an engineer soon", "We need to hold the destiny in our own hand. We should work hard for a better life in the future and it's not just saying". Only the coward expresses himself by the characters in games", "Don't be an ordinary person forever. Be yourself, an ideal self", "Life has ups and downs and the most important thing is to persevere and dare to change. Only by doing these can one achieve the final success", "I want to say to myself: Work hard for my own goal and do not make the efforts end in vain", "Never do what will cause regrets".

\section{DISCUSSION}

\subsection{Analysis}

The application of this group work in Values Education is to help students understand and master the theory of the conception of values, and define the conception of values. We set up activities of different themes, created a warm atmosphere for learning, and improved the interest in learning. According to the investigation results, the teaching method of the group work significantly improves the vocational college students' and university students' learning of the theory of the conception of values and realizes the education of values. It reached the expected results. The education method of the group work for values has stronger applicability and effectiveness. Moreover, the teaching mode of group work also 
satisfies students' development features and requirements. It is a kind of teaching mode that teaches through lively activities and loves to see and hear, from which students can benefit. It can be seen from students' insights that they are full of expectations and strength for the future. The reason why students are fond of the novel teaching form is exactly that they can benefit from it and that this kind of teaching form is thought to be helpful for them.

\subsection{Question discussion:}

Group Psychology Counseling can enhance the effectiveness of values education, but its chronicity and continuity on the guidance of students have not been validated. Though in a heated study environment and led by examples, the students learn related theories of the values, whether it could be implemented in practice and realize its own value or notrequires constant research and proof. The purpose of Group Psychology Counseling used in Values Education is not for consultation and treatment, but for providing a kind of chance for students to know and explore themselves, thus achieving the purpose of values education by means of psychological technologies, and then guiding students to learn the theories, internalize the moral conceptions and externalize the living practices. The education form of Group Psychology Counseling undoubtedly puts forward higher requirements for teachers. On the basis of understanding the value theory, they also need to study related knowledge of psychology, to be familiar with the design concept of group work, to be good at class management and to arouse students' activity and enthusiasm, so as to achieve teaching effectiveness.

\section{CONCLUSION}

The practice application of the group work in Values Education shows that compared with the traditional teaching method, the group work teaching method has better effectiveness, can help the students master the basic concept and connotation, and is more effective in helping students be clear about the values and build values. But the group work is just the teaching form of values education, and it should always focus on the syllabus in counseling to achieve the teaching goals.

\section{CONFERENCES}

[1] The Essence and Practice of Marxist Values, Xiang Du, Yang Xiaoling, Journal of Inner Mongolia University (philosophy and social science edition), issue 2, volume 44, March 2012

[2] Puzzlement and Outlet of Training on Spirit of Law of College Students. ZHANG Jia-yu, LI Zi-xuan. Journal of Beihua University (Social Sciences) 2014, 15(2).

[3] The Application of Group Counseling in the Teaching of An Introduction to Ideological, Moral and Legal Cultivation gongying Journal of Zhejiang Ocean University(Humane Science) 2012,29(5).

[4] An EmpiricaI Study of Group Guidance in Mental Health Education Course of College Students QIU Xiamyanl, TANG Jim2 JOURNAL OF EDUCATIONAL SCIENCE OF HUNAN NORMAL UNIVERSITY 2011, 10(1).

[5] Macan TH, Shahani C, Dipboye RL, et a1. CoHege students' tame management: Correlations with academic performance and stress. J Educ Psychol, 1990, 82(4): 760768.

[6] Britton BK, Tesser A. Effect of time-management practices on college grades. J EducPsychol, 1991, 83(3). 